\title{
Pembelajaran Limit Fungsi Berbasis Android Aplikasi Math Expert
}

\section{Fitria Khasanah}

Program Studi Pendidikan Matematika, Universitas Wisnuwardhana Malang

Coresponding author: fitria_kha@yahoo.com

\section{ART I CLE INFO}

Article history:

Received: Mei 2019

Accepted: September 2019

\section{Keywords:}

limit, android, math-

expert

\begin{abstract}
ABSTRAK
Perkembangan teknologi telah merubah perilaku manusia, termasuk siswa sekolah. Siswa sekolah pada saat ini tidak jarang yang menggunakan handphone, Sehingga tidak dapat dipungkiri bahwa kemajuan teknologi informasi dan komunikasi telah membawa perubahan yang signifikan dalam kehidupan sehari-hari. Matematika saat ini masih menjadi mata pelajaran yang kurang disenangi. Seiring dengan pesatnya perkembangan teknologi dan lahirnya generasi milenial arakternya sangat kuat dengan dunia digital, maka perlu mengintegrasikan kemajuan teknologi dalam proses pembelajaran. Tujuan dari penelitan ini adalah mengimplementasikan Pembelajaran Limit Fungsi Berbasis Android Melalui Aplikasi Math-Expert untuk meningkatkan motivasi belajar siswa. Penelitian ini merupakan penelitian kualitatif dengan mengambil sampel siswa kelas XI SMA Negeri 5 Malang tahun pelajaran 2017/2018. Dalam pengumpulan data, penelitian ini menggunakan angket motivasi belajar dan lembar observasi pembelajaran. Hasil penelitian ini menunjukkan bahwa selama pelaksanaan pembelajaran dengan mengimplementasikan aplikasi MathExpert mampu meningkatkan motivasi belajar siswa sebesar $7 \%$, selama proses pembelajaran siswa juga lebih aktif dan kreatif.
\end{abstract}

\section{PENDAHULUAN}

Sekolah sebagai lembaga pendidikan formal memiliki tanggung jawab besar dalam rangka mempersiapkan kebutuhan sumberdaya manusia yang handal dan siap menghadapi berbagai tantangan yang menghadang dimasa depan. Dalam dunia pendidikan seseorang akan mendapat berbagai pengetahuan, pengalaman, dan keterampilan. Hal tersebut sesuai dengan Undang-undang Republik Indonesia No. 20 Tahun 2003 tentang Sistem Pendidikan Nasional yaitu: mengembangkan kemampuan dan membentuk watak, serta peradaban bangsa yang bermartabat dalam rangka mencerdaskan kehidupan bangsa dan bertujuan untuk mengembangkan potensi peserta didik agar menjadi manusia beriman, bertaqwa kepada Tuhan Yang Maha Esa, berakhlak mulia, sehat, cakap, kreatif dan menjadi warga 
negara yang demokratis serta bertanggung jawab.

Dalam upaya mewujudkan fungsi pendidikan formal, sekolah dan guru diharapkan dapat memberikan motivasi belajar kepada siswa, karena motivasi yang kuat dapat mengantarkan siswa dalam mencapai prestasi belajar yang baik (Supriyatin, Miarsyah, \& Melia, 2017). Dalam proses pembelajaran matematika di SMA N 5 Malang terlihat ada dan kurangnya motivasi belajar pada siswa ketika sudah mulai membahas materi yang berkaitan dengan kalkulus yang dapat dilihat dari keaktifan siswa dalam proses belajar mengajar berlangsung. Sebagai contoh, siswa yang memiliki motivasi belajar yaitu siswa yaitu aktif dalam diskusi atau bertanya saat ia tidak mengerti, sebaliknya siswa yang kurang memiliki motivasi belajar dapat dilihat dari kebiasaanya yang kurang aktif dalam proses belajar mengajar seperti diam, dan takut bertanya saat ia kurang faham. Hal tersebut terjadi karena siswa memiliki motivasi berbeda-beda dalam setiap proses belajar mengajar (Ernawati, Heryanti, \& Mentari, 2017; Istiana, \& Awaludin, 2018). Untuk mengatasi maslah tersebut diperlukan suatu strategi untuk dapat meningkatkan motivasi belajar siswa yang kuat dan mendasar.

Proses belajar mengajar menurut Sudjana dan Rivai (1989: 27) adalah suatu proses komunikasi. Berkomunikasi merupakan kegiatan manusia sesuai dengan nalurinya yang selalu ingin berhubungan satu sama lain, dengan adanya naluri tersebut maka komunikasi dapat dikatakan bagian yang hakiki dari hidup manusia. Komunikasi mengandung makna menyebarluaskan informasi atau menyampaika pesan atau informasi dari sumber pesan (komunikator kepada penerima pesan (komunikan).

Media pembelajaran mnurut Usman, (2002: 14) merupakan salah satu unsur yang penting dalam proses belajar mengajar yang dapat dimuati pesan yang akan disampaikan kepada siswa baik berupa alat, orang maupun bahan ajar. Selain itu, media pembelajaran dapat merangsang siswa agar lebih efektif. Oleh karena itu, maka penggunaan media pembelajaran dapat merangsang siswa untuk belajar.

Ketepatan memilih media pendidikan yang akan digunakan dalam proses belajar mengajar sangat besar pengaruhnya terhadap efektifitas tercapainya tujuan pendidikan dan pengajaran yang akan di capai (Rosamsi, Miarsyah, \& Ristanto, 2019; Permana \& Chamisijatin, 2019). Dalam proses mengajar sering terjadi tidak efektif dan efisien disebabkan oleh adanya kurang minat,kurang gairah dan sebagainya. Keberadaan media dalam pembelajaran dimaksudkan untuk memudahkan dalam penyampaian pesan pembelajaran, memudahkan pemahaman, mempunyai retensi (daya ingat) yang lama, serta dapat diaplikasikan dalam waktu dan kesempatan yang lain dibutuhkan.

Media pembelajaran akan memudahkan siswa menerima dan mengingat materi yang telah disampaikan manfaat lain, akan memudahkan guru dalam menyampaikan materi, karena dapat ditunjukan secara langsung kepada siswa, suatu bukti konkrit berupa suara dan gambar gerak karena media pembelajaranberhubungan langsung dengan indera penglihatan dan pendegaran (Suryanda, Ernawati, \& Maulana, 2016). Azhar Arsyad (2003: 15) mengemukakan bahwa pemakaian media dalam proses belajar mengajar dapat membangkitkan keingintahuan dan minat baru bagi siswa,serta membangkitkan motivasi dan rangsangan kegiatan belajar mengajar dan bahkan membawa pengaruh psikologis terhadap siswa.

Dengan demikian dapat disimpulkan bahwa penggunaan media pembelajaran tidak hanya sebagai upaya untuk membantu guru dalam mengajar tetapi juga sebagai usaha yang ditujukan untuk memudahkan siswa dalam mempelajari materi limit fungsi. Dari latar belakang masalah diatas, maka permasalahan yang dapat peneliti ugkapkan dalam pembuatan penelitian ini adalah bagaimana peranan media pembelajaran terhadap motivasi belajar siswa dalam mempelajari materi limit? Dalam hal ini media pembelajaran yang digunakan adalah aplikasi math expert dengan menggunakan Android.

Math Experts mrupakan aplikasi yang menyediakan berbagai rumus matematika, 
fisika, teknik elektro, dan kimia. Semuanya rumus diatur berdasarkan kategorinya, seperti rumus trigonometri pada kategori matematika, dan rumus massa pada kategori fisika. Pembagian ini juga memudahkan pengguna dalam menyelesaikan berbagai soal dengan mudah.

Pengguna cukup mencari kategori soal yang ingin dipecahkan dan memasukkan angka-angka pada kolom yang telah disediakan. Setelah itu tap tombol Calculate untuk menemukan jawabannya. Math Experts juga menyediakan fitur grafik untuk soal-soal tertentu. Akan tetapi aplikasi ini tidak menjabarkan langkah demi langkah dalam menyelesaikan soal. Pengguna hanya dapat melihat jawaban tanpa tahu proses memecahkan soalnya.

Berikut adalah contoh penerapan math expert dalam materi limit. Jika soal yang diberikan seperti gambar di bawah ini

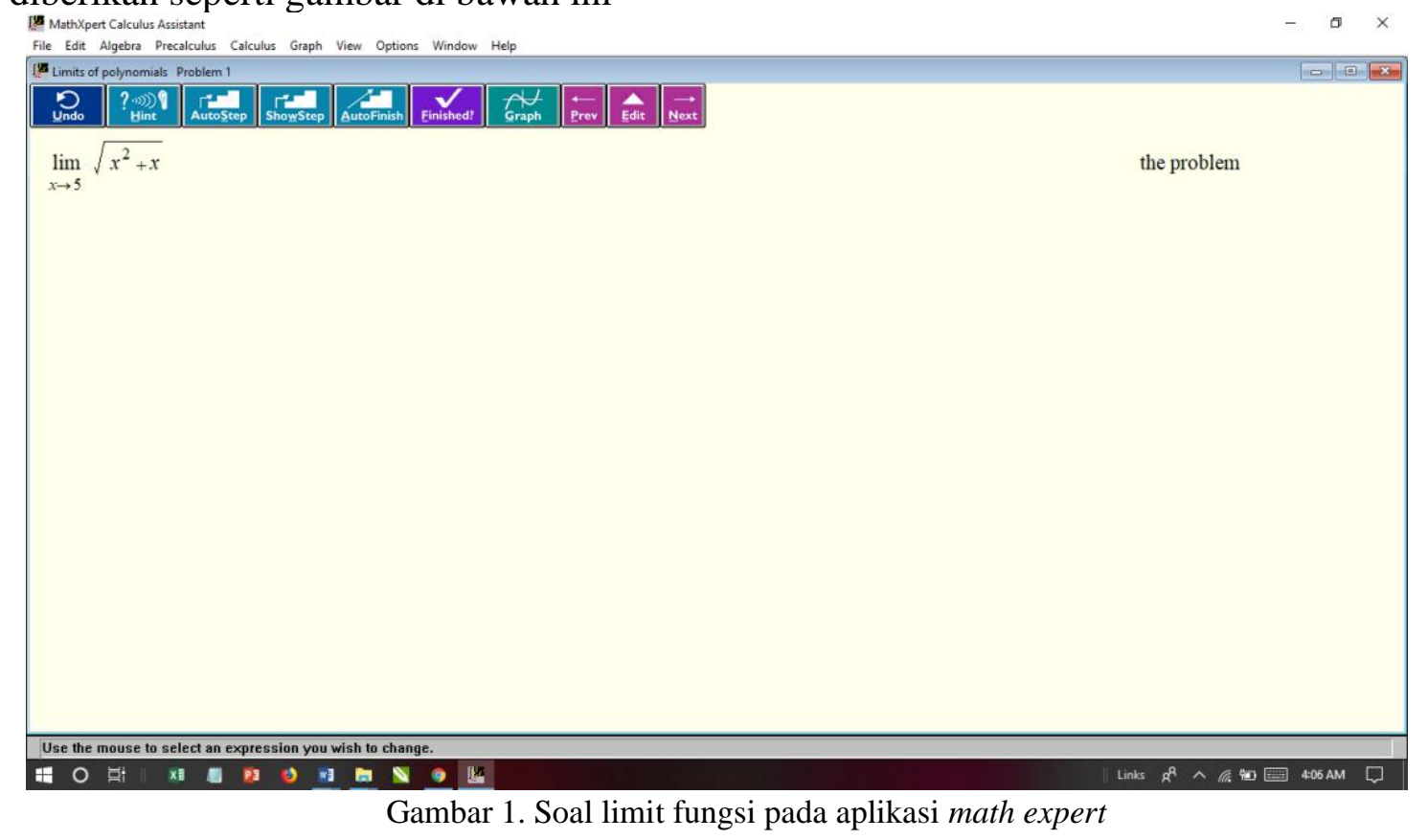

maka pemanfaatan math expert dapat meliputi

a. Menjelaskan langkah demi langkah penyelesaian limit fungsi maka pilih "auto step"

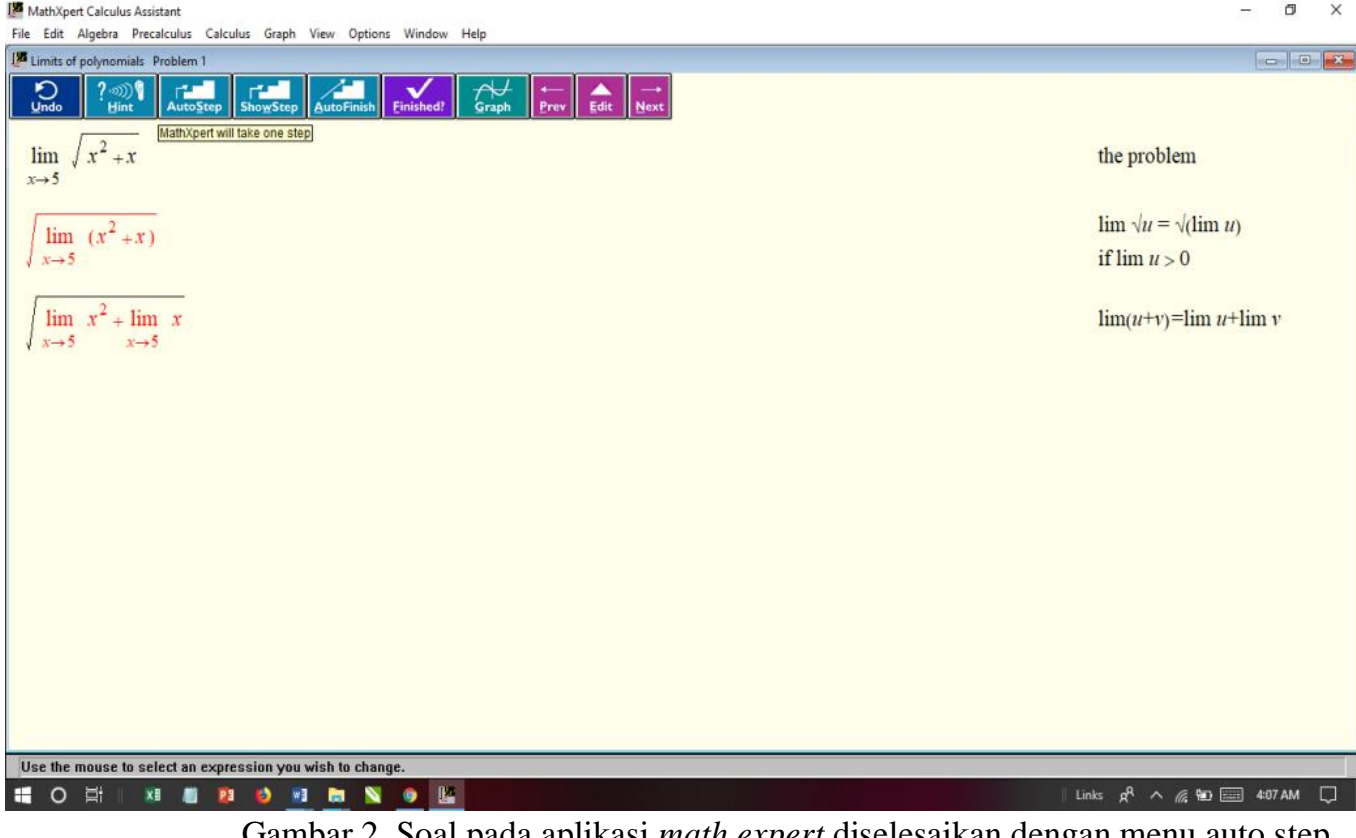

Gambar 2. Soal pada aplikasi math expert diselesaikan dengan menu auto step 
b. Menjelaskan langkah demi langkah proses penyelesaian limit fungsi maka pilih "show step"

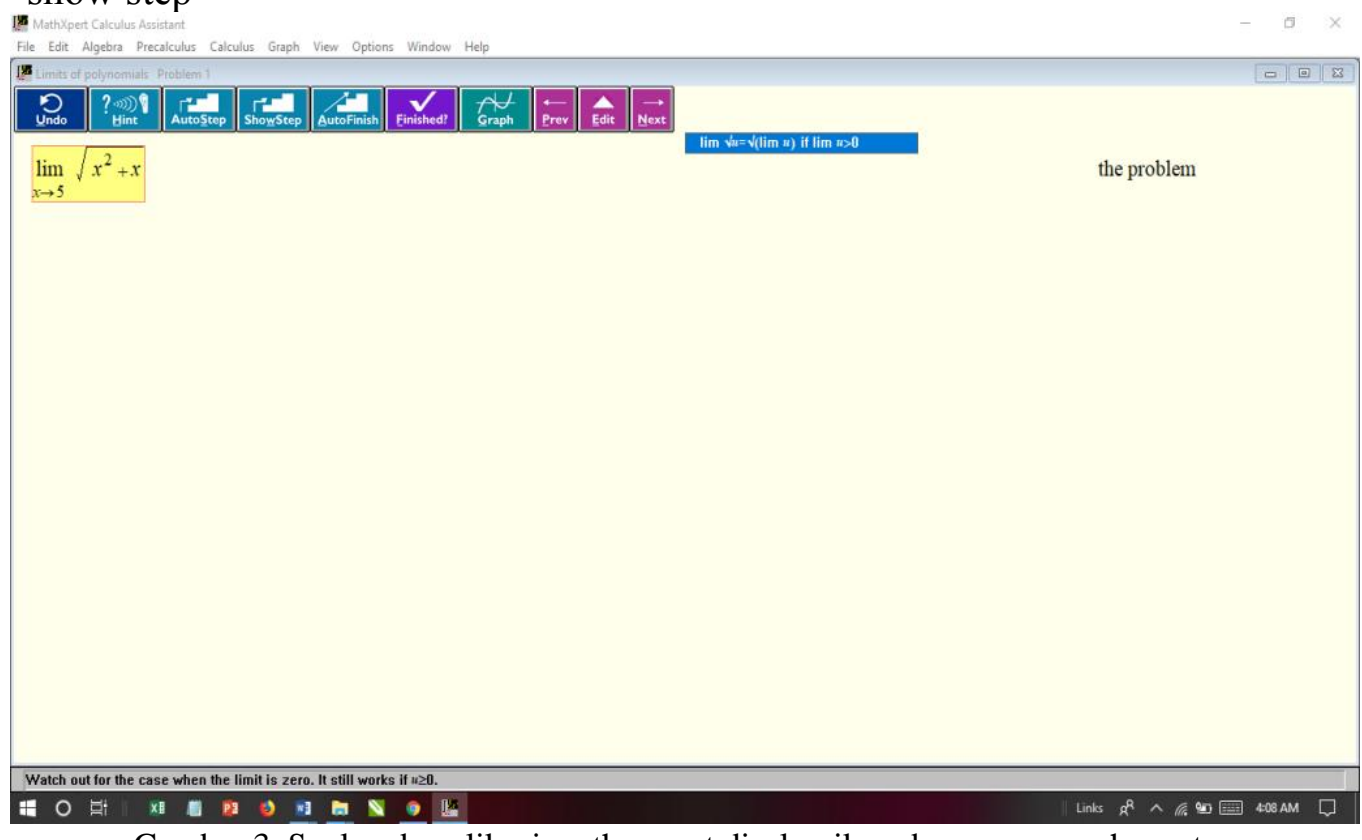

Gambar 3. Soal pada aplikasi math expert diselesaikan dengan menu show step

c. Langsung pada penyelesaian akhir soal limit fungsi maka pilih "auto Finish"

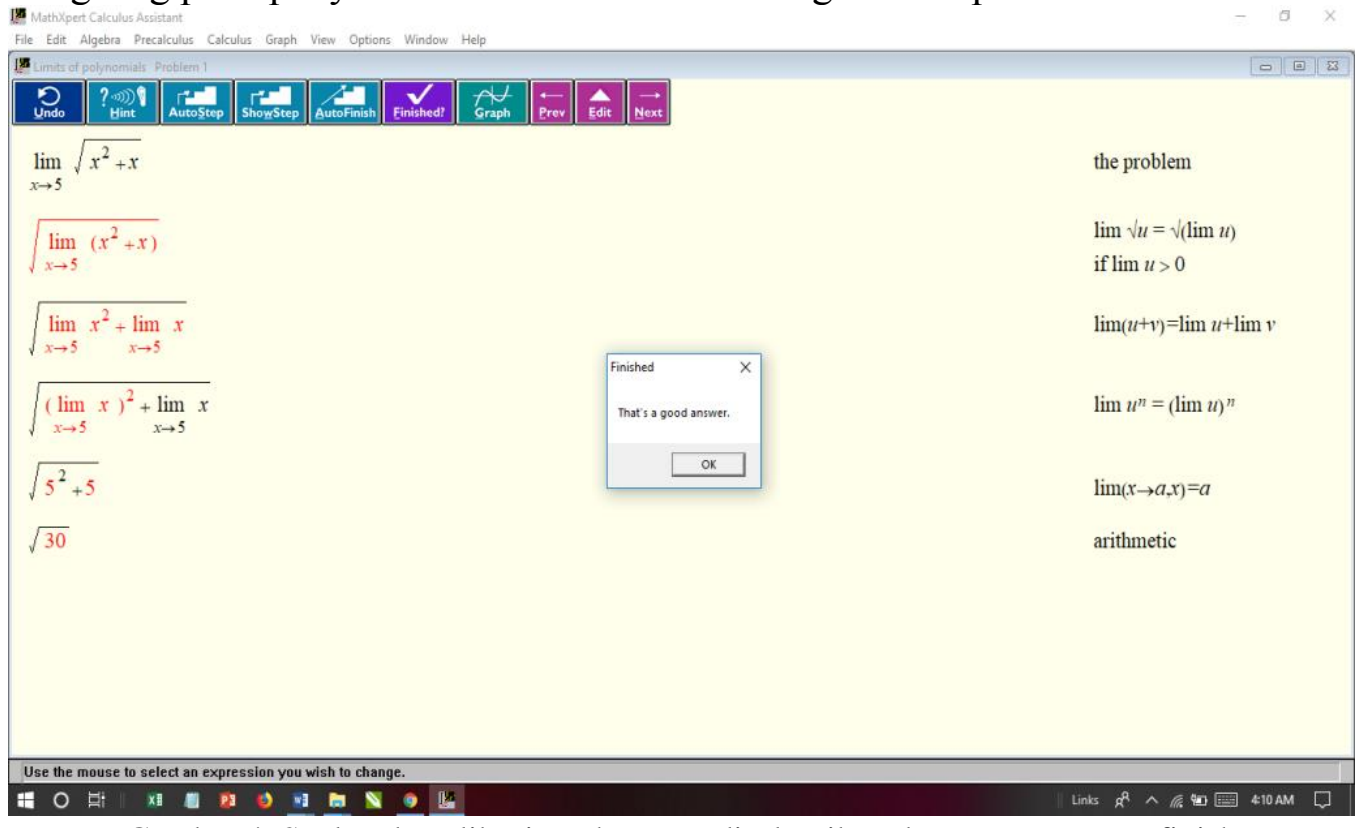

Gambar 4. Soal pada aplikasi math expert diselesaikan dengan menu auto finish

Mudjiman (2006:37) menyatakan bahwa motivasi belajar adalah kekuatan pendorong dan pengarah dalam belajar. Yang dimaksud dengan pendorong adalah pemberi kekuatan yang memungkinkan kegiatan belajar dilakukan. Pengarah berarti memberikan tuntunan agar kegiatan belajar menuju titik tujuan yang telah ditetapkan. Sardiman (2007:75) dan Ristanto (2009) menyatakan bahwa motivasi dalam pembelajaran sebagai keseluruhan daya penggerak yang ada di dalam diri siswa untuk melakukan kegiatan belajar. Motivasi memiliki peranan yang khas dalam menumbuhkan gairah, perasaan senang, dan semangat untuk belajar pada siswa. 
Berdasarkan asalnya, motivasi belajar dibedakan menjadi dua yaitu motivasi intrinsik yang berasal dari dalam diri siswa dan motivasi ekstrinsik yang berasal dari luar diri siswa. Kedua motivasi ini mendorong siswa untuk menguasai suatu kompetensi guna mengatasi masalah. Motivasi intrinsik ada dalam kegiatan-kegiatan tanpa paksaan, sedangkan letak pendorong atau penyebab perbuatan ada di dalam diri pelaku perbuatan tersebut. Motivasi ekstrinsik merupakan faktor pendorong yang berasal dari luar diri pelaku perbuatan. Seorang siswa yang belajar karena didorong oleh motivasi ekstrinsik akan mengharapkan reward (penghargaan) atau menghindari punishment (hukuman).

\section{METODE}

Metode penelitian ini adalah deskriptif kualitatif. Penelitian ini dilaksanakan di kelas pada XI MIA 3. Data penelitian dikumpulkan dengan menggunakan teknik (a) dokumentasi, dan (b) angket. Teknik dokumentasi merupakan metode untuk memperoleh atau mengetahui sesuatu yang berhubungan dengan yang diteliti. Dokumentasi yang digunakan adalah (a) daftar nama siswa, dan (b) foto kegiatan pembelajaran. Teknik angket digunakan untuk menggali data tanggapan dan kesan siswa tentang proses pembelajaran sebelum tindakan dan setelah pelaksanaan tindakan. Dan digunakan untuk mengetahui tingkat motivasi belajar siswa.

Untuk menguji keabsahan data dalam penelitian ini penulis menggunakan cara triangulasi yaitu diskusi dengan teman sejawat (kolaborator). Data dianalisis bersama mitra kolaborator. Untuk kesinambungan dan kedalaman dalam penganalisisan data dalam penelitian ini digunakan analisis interaktif. Bentuk interaktif pengumpulan data sebagai suatu proses siklus. Teknik analisis data yang digunakan mengacu pada pendapat Miles \& Huberman dalam Aqib (2006) yang mencakup (a) pengumpulan data, (b) reduksi data, dan (c) penarikan kesimpulan.

Untuk mengetahui motivasi belajar siswa dalam pembelajaran limit fungsi. Adapun penentuan tinggi rendahnya motivasi belajar siswa dapat dilakukan dengan membagi skor perolehan angket siswa dibagi jumlah soal. Selanjutnya, rerata tersebut dikonfirmasikan dengan pengelompokan tingkat motivasibelajar siswa dengan menggunakan tabel berikut ini.

\begin{tabular}{lll} 
& Tabel 1. Kategori Motivasi Belajar Siswa \\
\hline No & Rata-rata Skor & Kategori \\
\hline 1. & $\geq 4.00$ & Sangat tinggi \\
2. & $3.00-3.99$ & Tinggi \\
3. & $2.00-2.99$ & Sedang \\
4. & $1.00-1.99$ & Rendah \\
5. & $\leq 0.99$ & Sangat rendah \\
\hline
\end{tabular}

\section{HASIL DAN PEMBAHASAN}

Pelaksanaan proses pembelajaran berbantuan math expert bertujuan untuk meningkatkan motivasi belajar siswa pada materi limit fungsi. Pelaksanaan penelitian terdiri dari 2, dimana setiap sesi terdapat 4 tahap penelitian yaitu (1) Perencanaan (Planning) yaitu guru mempersiapkan silabus, mempersiapkan rencana pembelajaran berbantuan math expert, mempersiapkan materi yang akan diajarkan yaitu limit fungsi aljabar dan trigonometri, mempersiapkan bahan ajar tentang pengertian limit fungsi menggunakan math expert, dan mempersiapkan perlengkapan yang dibutuhkan dalam pembelajaran berbantuan math expert yaitu laptop dan LCD. (2) Tindakan yaitu secara umum guru menjelaskan tujuan pembelajaran dan memotivasi siswa untuk mempelajari materi limit fungsi. Langkah selanjutnya guru menjelaskan materi pembelajaran dengan 
menayangkan bahan ajar pada layar LCD kemudian menayangkan latihan-latihan soal untuk dikerjakan oleh siswa dengan menulis di lembar jawab LKM dan mengujicoba dengan menggunakan android siswa yang sudah diinstal aplikasi math expert dan mengakhiri pembelajaran dengan doa. (3) Observasi dilaksanakan terhadap proses pembelajaran yang berlangsung pada setiap sesi, hasil analisi data hasil kegiatan pembelajaran dan angket motivasi belajar siswa. (4) Refleksi dilakukan berdasarkan hasil observasi dan catatan lapangan yang dilaksanakan pada saat tindakan. Pada refleksi sesi 1 hasil observasi menunjukkan bahwa ada beberapa hal yang perlu diperbaiki setelah proses pembelajaran berbantuan math expert untuk dilaksanakan pada sesi ke 2 .

Tabel 2. Hasil Penghitungan Hasil Angket Sesi 1

\begin{tabular}{llc}
\hline Indikator & Pra Sesi & Sesi I \\
\hline Rasa senang dalam belajar matematika & $62,50 \%$ & $62,04 \%$ \\
\hline Aktif dalam pembelajaran matematika & $60,07 \%$ & $71,18 \%$ \\
\hline Kreatif dalam mempelajari matematika & $72,78 \%$ & $78,89 \%$ \\
\hline Rata-rata & $65,12 \%$ & $70,70 \%$ \\
\hline
\end{tabular}

Tabel diatas menunjukkan bahwa siswa yang berminat dalam pembelajaran matematika mengalami peningkatan dari $65,12 \%$ pada pra sesi menjadi $70,70 \%$ setelah sesi 1.

Penelitian dengan memanfaatkan android dengan aplikasi MATH EXPERT pada siswa dilaksanakan sebanyak 2 sesi. Pada sesi 1, dari hasil observasi dapat diketahui bahwa siswa senang dengan pembelajaran berbantuan MATH EXPERT. Hal ini terlihat dari respon siswa yang antusias menjawab pertanyaan ataupun soal-soal yang ditayangkan guru pada layar LCD. Siswa juga antusias menanggapi tugas dari guru untuk mencari bahan pelajaran mengenai limit fungsi di internet. Akan tetapi ada beberapa hal yang perlu diperbaiki setelah proses pembelajaran berbantuan MATH EXPERT dilaksanakan. Persentase siswa yang aktif maju mengerjakan di papan tulis masih belum sesuai dengan indikator penelitian. Siswa masih kelihatan malu untuk mengerjakan dan menjelasakan soal latihan di papan tulis dan hanya berani menjawab pertanyaanpertanyaan secara lisan dan bersama-sama. Beberapa siswa masih terlihat melakukan aktivitas yang tidak relevan dengan pembelajaran. Ada beberapa siswa yang bercanda dan bahkan bermain gawai dengan multi window. Selain itu, siswa terlihat malu mengajukan pertanyaan ketika guru memberikan kesempatan untuk bertanya. Hasil angket yang dilakukan pada sesi 1 menunjukkan bahwa ada peningkatan yang cukup signifikan antara hasil angket sebelum dan setelah penerapan pembelajaran berbantuan MATH EXPERT. Sebelum penerapan pembelajaran berbantuan MATH EXPERT, terdapat sekitar $65,12 \%$ siswa yang telah memiliki motivasi belajar yang baik, dan setelah penerapan pembelajaran berbantuan MATH EXPERT sekitar 70,70\% siswa telah memiliki motivasi yang lebih baik. Hasil penghitungan data hasil angket sesi 2 dapat dilihat pada tabel berikut: 


\begin{tabular}{llll}
\hline Indikator & Pra Sesi & Sesi I & Sesi II \\
\hline Rasa senang dalam belajar matematika & $62,50 \%$ & $62,04 \%$ & $76,39 \%$ \\
\hline Aktif dalam pembelajaran matematika & $60,07 \%$ & $71,18 \%$ & $74,65 \%$ \\
\hline Kreatif dalam mempelajari matematika & $72,78 \%$ & $78,89 \%$ & $78,33 \%$ \\
\hline Rata-rata & $65,12 \%$ & $70,70 \%$ & $76,46 \%$ \\
\hline
\end{tabular}

Dari tabel diatas menunjukkan bahwa persentase siswa yang berminat mengalami peningkatan dari 70,70\% pada saat sesi 1 menjadi 76,46\% pada sesi 2. Minat siswa dalam pembelajaran matematika pada sesi 2 termasuk dalam kategori tinggi.

Pada sesi 2, dari data observasi siswa ada peningkatan persentase keaktifan siswa. Hal tersebut terlihat ketika kegiatan pembelajaran pada pertemuan pertama banyak siswa yang terlihat masih malu berpendapat, pada sesi kedua siswa lebih antusias untuk mengerjakan soal latihan di dalam kelompok. Sehingga lebih banyak soal latihan yang selesai dikerjakan siswa. Meski masih ditemukan siswa yang masih didapati melakukan aktivitas yang tidak relevan dengan pembelajaran. Hasil diskusi kelompok juga menunjukkan peningkatan terlihat lebih aktif. Siswa yang lebih aktif atau motivasinya meningkat juga lebih banyak yaitu sekitar 76,46\% sehingga pada sesi kedua motivasi siswa telah memenuhi indikator keberhasilan. Dari uraian di atas dapat disimpulkan bahwa pembelajaran yang dilakukan pada sesi 2 telah cukup baik Berdasarkan keadaan tersebut menunjukkan bahwa telah terjadi peningkatan motivasi belajar siswa di kelas dan proses pembelajaran telah berjalan dengan efektif.

\section{KESIMPULAN}

Penerapan aplikasi MATH EXPERT dapat meningkatkan motivasi belajar matematika siswa pada materi limit fungsi. Sebelum penerapan pembelajaran berbantuan MATH EXPERT, banyaknya siswa yang termotivasi untuk belajar adalah $65,12 \%$, setelah penerapan pembelajaran berbasis android dengan aplikasi MATH EXPERT pada sesi 1 meningkat menjadi 70,70\% dan pada sesi 2 meningkat menjadi 76,46\%. Dengan demikian dapat disimpulkan bahwa pembelajaran matematika berbasis android dengan aplikasi math expert dapat meningkatkan motivasi belajar siswa terhadap materi limit fungsi.

\section{DAFTAR PUSTAKA}

Anderson, L.W., dan Krathwohl, D.R. (2001). A Taxonomy for Learning, Teaching, and Assesing: A Revision of Bloom's Taxonomy of Educatioanl Objectives. New York: Addison Wesley Longman, Inc.

Ernawati, Heryanti, E., \& Mentari, N. T. (2017). Hubungan self efficacy dengan motivasi siswa dalam berwirausaha berbasis biologi. Biosfer: Jurnal Pendidikan Biologi, 10(1), 50-57.

Gagne, R.M., Briggs, L.J \& Wager, W.W. (1988). Principles of Instruction Design, 3rd ed. New York: Saunders College Publishing.

Istiana, R., \& Awaludin, M. T. (2018). Enhancing biology education students ability to solve problems in environmental science material through inquiri model-based lesson study. Biosfer: Jurnal Pendidikan Biologi, 11(1), 57-66.

Kemmis, S. dan MC. Taggart.R. Ed.(1988). The Action Resesarch Planner. Deakin. Deakin University: Australia

Permana, F. H., \& Chamisijatin, L. (2019). Project-based learning through edmodo: 
improving critical thinking and histology concepts. Biosfer: Jurnal Pendidikan Biologi, 12(1), 58-69.

Rosamsi, S., Miarsyah, M., \& Ristanto, R. H. (2019). Interactive multimedia effectiveness in improving cell concept mastery. Journal of Biology Education, 8(1), 56-61.

Ristanto, R. H. (2010). Pembelajaran Berbasis Inkuiri Terbimbing Dengan Multimedia Dan Lingkungan Riil Ditinjau Dari Motivasi Berprestasi Dan Kemampuan Awal. Unpublished Masters Thesis), Universitas Sebelas Maret, Surakarta.

Sardiman. (2007). Interaksi dan Motivasi Belajar Mengajar. Jakarta: Raja Grafindo Persada.

Sudjana, N. \& Rivai, A. (1992). Media Pengajaran. Bandung: Penerbit CV. Sinar Baru Badung.

Supriyatin, S., Miarsyah, M., \& Melia, M. (2017). Hubungan antara persepsi siswa tentang gaya kepemimpinan transaksional guru dengan motivasi belajar biologi siswa. Biosfer: Jurnal Pendidikan Biologi, 10(1), 45-49.

Suryanda, A., Ernawati, E., \& Maulana, A. (2016). Pengembangan modul multimedia mobile learning dengan android studio 4.1 materi keanekaragaman hayati bagi siswa sma kelas x. Biosfer: Jurnal Pendidikan Biologi, 9(1), 55-64.

Ngatimin \& Sahat. (2004). http://myschoolnet.ppk.kpm.my/bhn_pnp/bs_kbsm_sej5.pdf, diakses 8 Oktober 2007). 